\title{
Peran Public Relations dalam Meningkatkan Citra PT. Jaya Perkasa Wibawa
}

\author{
Chyntia Agustina Sunardi ${ }^{1}$, Farid ${ }^{2 *}$ \\ ${ }^{1}$ Fakultas Ilmu Komunikasi, Universitas Tarumanagara, Jakarta \\ Email: chyntia.915180148@stu.untar.ac.id \\ ${ }^{2}$ Fakultas Ilmu Komunikasi, Universitas Tarumanagara, Jakarta* \\ Email: farid@fikom.untar.ac.id
}

Masuk tanggal: 15-12-2021, revisi tanggal: 06-01-2022, diterima untuk diterbitkan tanggal: 16-01-2022

\begin{abstract}
The background of this research is to examine how the role of Public Relations in improving the company's image and maintaining the company's image so that this image can be achieved. This study uses public relations theory and image theory with descriptive qualitative research methods through case studies. Data collection is done by indepth interviews, observation and documentation. The results of this study that the role of Public Relations can improve the company's image, Public Relations from PT. Jaya Perkasa Wibawa is quite good at maintaining the relationship between internal stakeholders within the company and the image of PT. Jaya Perkasa Wibawa can also be classified as good.
\end{abstract}

Keywords: image, public relations, role

\begin{abstract}
Abstrak
Latar belakang dari penelitian ini adalah peneliti ingin meneliti bagaimana peran Public Relations dalam meningkatkan citra perusahaan dan mempertahankan citra perusahaan. Penelitian ini menggunakan teori public relations dan teori citra dengan metode penelitian kualitatif deskriptif melalui studi kasus yang pengambilan datanya dilakukan dengan cara wawancara, observasi dan dokumentasi. Hasil dari penelitian ini bahwa peran Public Relations dapat meningkatkan citra perusahaan, Public Relation dari PT. Jaya Perkasa Wibawa cukup baik menjaga hubungan antara individu dalam perusahaan. Citra yang dimiliki PT. Jaya Perkasa Wibawa juga sudah dapat digolongkan baik.
\end{abstract}

Kata Kunci: citra, peran, public relations

\section{Pendahuluan}

Saat ini perkembangan ekonomi dan gaya hidup yang tengah terjadi di dunia memberikan pengaruh besar terhadap kehidupan manusia khusunya dalam hal pemuasan kebutuhan. Dahulu manusia hanya memenuhi tiga kebutuhan pokok saja yaitu papan, pangan dan sandang. Namun seiring dengan perkembangan zaman, saat ini rasa aman menjadi sebuah tuntutan bagi sebagian orang. Seperti halnya perlindungan akan dirinya sendiri, keluarga, juga perlindungan di hari tua (dana pensiun). Dari sebagian orang memerlukan asuransi untuk memenuhi kebutuhan yang belum pasti di masa yang akan datang. Dalam hal ini, asuransi telah dianggap sebagai salah satu suatu kenutuhan. Asuransi dapat diartikan sebagai suatu buah pikir akan budi manusia guna mencapai suatu keadaan yang dapat memenuhi kebutuhan. Faktor utama nya itu ialah kebutuhan yang bersifat hakiki antara lain rasa aman dan terlindungi (Fauziyah, 2017). 
Dikarenakan kepemilikan asuransi bagi masyarakat dinilai begitu berarti, maka kebutuhan akan jasa perlindungan asuransi semakin dirasakan, baik oleh perorangan maupun dunia usaha di Indonesia. Asuransi adalah suatu perjanjian, seorang penanggung mengikatkan diri pada tertanggung dengan mendapatkan suatu asuransi, untuk menyampaikan pengganti kepadanya sebab adanya suatu kerusakan, kerugian atau kehilangan laba yg diperlukan, yang mungkin terjadi karena suatu insiden yg tidak sempurna (Aspek Hukum Perjanjian Asuransi - Tuti Rastuti - Google Buku, n.d.). Asuransi memiliki beberapa manfaat yang sangat mendasar. Pertama, asuransi dapat membantu nasabah dalam mengatasi segala masalah yang dihadapinya. Hal ini dapat memberikan kenyamanan dan suatu kepercayaan dari nasabah. Ke dua, dalam kepentingan masyarakat, asuransi merupakan sarana yang tepat dalam pengumpulan dana yang cukup besar bagi suatu perusahaan sehingga hal ini dapat dimanfaatkan sebagai dana pembangunan. Ketiga, asuransi juga merupakan alat untuk mengatasi risiko yang dapat dihadapi dalam menjalankan pembangunan.

Di tengah pandemi seperti ini, banyak risiko atau dampak yang dialami masyarakat sebagai akibat dari pandemi Covid-19. Tidak hanya masalah kesehatan yang terdampak namun kehidupan seosial masyarakat juga mengalami imbasnya, termasuk urusan pendidikan hingga ekonomi (Kennedy dan Suhendarto, 2020; Pradana dan Nur'aini, 2020; Dewi, 2020; Pakpahan, 2020; Syafrida dan Hartati, 2020). Salah satunya yaitu aspek keamanan yang bisa didapatkan dari asuransi jiwa. Kepemilikan asuransi sangatlah dibutuhkan, apalagi peraturan yang dikeluarkan oleh pemerintah, salah satunya penerapan pembatasan sosial berskala besar atau PSBB kini tengah membatasi segala aktivitas masyarakat. Sehingga sebagai upaya memasarkan produk asuransi tentunya perusahaan harus menentukan strategi-strategi bagaimana memanfaatkan peran dari Public Relations.

PT. Jaya Perkasa Wibawa adalah salah satu perusahaan yang bergerak dalam bidang jasa keperantaraan dengan menganalisis dan menempatkan risiko yang dihadapi principal atau bertanggung jawab kepada asuransi dan bank yang memadai yang kini juga harus menghadapi persaingan yang cukup ketat dengan perusahaan asuransi lainnya. Supaya PT. Jaya Perkasa Wibawa dapat bertahan dan berkembang dengan baik, maka harus bisa menciptakan kemampuan dalam hal bersaing dengan perusahaan lainnya, baik itu dalam hal pelayanan, harga yang lainnya sehingga dapat menghasilkan produk yang mampu bersaing dan dapat memenangkan persaingan. Pelayanan yang diberikan oleh PT. Jaya Perkasa Wibawa di antaranya adalah survey resiko dan survey klaim; penilaian risiko; pengelola risiko; pencegahan kerugian; merancang program asuransi yang sesuai dengan risiko yang dihadapi nasabah; mencari perusahaan asuransi yang terseleksi, berkualitas dan terpercaya; dokumentasi; dan penanganan penyelesaian klaim. Berdasarkan uraian di atas, maka untuk mengetahui dan menganalisa lebih dalam bagaimana peran Public Relations dalam meningkatkan citra PT. Jaya Perkasa Wibawa.

\section{Metode Penelitian}

Peneliti memilih metode penjaringan data penelitian melalui pendekatan studi kasus dan kualitatif deskriptif. Metode studi kasus merupakan rangkaian kegiatan ilmiah yang dilakukan secara intensif, rinci serta mendalam dalam kaitannya dengan suatu program, peristiwa atau kegiatan pada tingkat individu, sekelompok orang, lembaga atau organisasi guna memperoleh pengetahuan yang lebih dalam perihal peristiwa tersebut. umumnya, acara yang dipilih, selanjutnya dianggap acara, artinya 
hal yang sedang terjadi insiden kehidupan), bukan apa yang sudah berlalu. Sedangkan kualitatif deskriptif ini merupakan proses memperoleh data yang bersifat apa adanya dan lebih menekankan makna pada hasilnya (Sugiyono, 2015).

Alasan mengapa peneliti memilih metode ini agar pengetahuan dan wawasan dapat terus meningkat melalu eksplorasi dan kolaborasi antara apa yang terlihat dan yang dipikirkan dengan pemikiran yang mendalam. Selain itu, hal ini mengasah para pelanggan untuk memiliki pengetahuan dan kecerdasan yang lebih melalui pengamatan terkait data-data yang dilampirkan.

Dalam penelitian kualitatif, subyek penelitian biasa disebut dengan istilah sebagai informan atau narasumber. Dalam hal ini narasumber akan memberikan informasi selengkap-lengkapnya dan data-data yang diperlukan oleh penulis untuk menyelesaikan penelitian tersebut. Menurut (Sugiyono, 2015) peneliti dan narasumber memiliki posisi yang sama, dan narasumber bukan sekadar memberikan tanggapan yang diminta peneliti, tetapi bisa memiliki arah dan selera dalam menyajikan informasi yang ia miliki. Dalam menentukan narasumber atau informan, peneliti harus memilih atas dasar kriteria yang sesuai dengan penelitian. Subyek yang digunakan adalah manusia yang berperan sebagai narasumber yang berasal dari tenaga kerja di PT Jaya Perkasa Wibawa yang menunjang data-data dalam penelitian ini. Sedangkan, obyek yang menjadi fokus utama dalam penelitian ini adalah pemanfaatan peran Public Relations PT Jaya Perkasa Wibawa dalam meningkatkan citra PT Jaya Perkasa WIbawa.

\section{Hasil Temuan dan Diskusi}

\section{Peran Public Relations dalam Meningkatkan Citra Perusahaan PT Jaya Perkasa Wibawa Melalui Public Internal}

Citra yang dimiliki PT Jaya Perkasa Wibawa sudah dapat digolongkan baik. Adi selaku karyawan teknik PT.Jaya Perkasa Wibawa menyampaikan bahwa selama tujuh tahun bekerja di bawah naungan PT Jaya Perkasa Wibawa, ia telah mendapatkan banyak perubahan bermakna dari segi pengalaman, pembelajaran, serta pendapatan. Komunikasi antar individu dalam ruang lingkup perusahaan pun terjaga dengan cukup baik.

Kendati demikian, Andri Sumanjaya yang berperan sebagai Public Relations sekaligus General Manager beranggapan bahwa terlepas dari keuntungan yang didapat dari bekerja di PT Jaya Perkasa Wibawa, karyawan terkadang mengalami hambatan ketika mempromosikan layanan. Hambatan tersebut ada dikarenakan beberapa sumber daya manusia yang dimiliki PT Jaya Perkasa Wibawa belum mumpuni dalam bidang promosi serta teknologi. Beberapa dari mereka tidak terlalu mahir menggunakan media sosial, sehingga proses promosi dilakukan dari mulut ke mulut, bukan digital (wawancara langsung dengan Andri Sumanjaya pada 4 November 2021 pukul 10.58 WIB).

Menurut observasi penulis, PT Jaya Perkasa Wibawa juga belum memanfaatkan media sosial sebagai wadah untuk menampung kritik, saran, maupun ulasan klien, memberikan informasi, juga menjalin interaksi dengan calon klien. PT Jaya Perkasa Wibawa hanya memiliki satu website resmi, yakni http://jpwconsultant.blogspot.com/2018/02/kontak-kami.html. Hambatan tersebut akan mempersulit perusahaan untuk meningkatkan citra positif yang dimilikinya. Oleh karena itu Andri mengatakan ke depannya perusahaan akan menangani kondisi 
tersebut dan berfokus untuk memperbaikinya lagi sehingga perusahaan dapat berkembang. Misalnya dengan membuat akun media sosial resmi perusahaan dan mengadakan pelatihan khusus penggunaan media sosial sebagai media pemasaran bagi para karyawan PT Jaya Perkasa Wibawa.

"Untuk hambatan pertama, kita kurang sumber daya manusia. Kurang menguasai bidang untuk promosi itu. Yang lainnya adalah, dari segi teknologi beberapa staf kita belum menguasai lewat media sosial, Jadi, lebih kehambat di SDM dan teknologi ..."

Cara meningkatkan citra PT Jaya Perkasa Wijaya dari sisi internal lainnya adalah dengan terus membekalkan karyawan dan staf pembelajaran serta ilmu-ilmu yang bermanfaat dalam bidang pekerjaannya. Dengan ilmu yang terus bertambah, secara otomatis kinerja juga dapat menjadi lebih baik lagi. Lalu, citra positif milik perusahaan yang dinaunginya, yaitu PT Jaya Perkasa Wijaya pun akan meningkat (wawancara langsung dengan Santana Adi Kusuma pada 4 November 2021 pukul $10.58 \mathrm{WIB})$.

\section{Peran Public Relations dalam Meningkatkan Citra Perusahaan PT Jaya Perkasa Wibawa Melalui Public Eksternal}

PT Jaya Perkasa Wibawa menjadi pilihan publik karena perusahaan agen bank asuransi tersebut dikenal memiliki pelayanan yang cepat, layanan produk dan jasa yang beragam, serta tawaran harga yang terjangkau. Namun, Antonious Bayu Cahyadi yang menjabat sebagai Direktur Utama PT Jaya Perkasa Wibawa ingin meningkatkan lagi citra perusahaannya di mata publik. Ia ingin public mengenal PT Jaya Perkasa Wibawa sebagai perusahaan dalam bidang jasa keperantaraan yang dapat membantu Usaha Mikro Kecil Menengah (UMKM) dari sisi pinjamang. Untuk meningkatkan citra tersebut, PT Jaya Perkasa Wibawa memiliki strategi yang tidak jauh beda dengan strateginya dalam mempertahankan citra yang dimilikinya saat ini, yaitu memberikan pelayanan terbaik dan bekerja sama dengan Himpunan Bank Negara (wawancara langsung dengan Antonius Bayu Cahyadi pada 4 November 2021 pukul 10.58 WIB).

Upaya dalam memberikan pelayanan terbaik dapat dilihat dari tindakan Public Relations yang melakukan analisis persaingan secara terus-menerus supaya tidak pernah terlewatkan akan kondisi pasar terbaru. Dikarenakan tidak semua bank memiliki aturan maupun penawaran yang sama, PT Jaya Perkasa Wibawa akan melakukan survei pasar secara rutin. Para staf akan mengumpulkan perbedaan setiap bank maupun keunggulan yang mereka miliki, kemudian memilah yang paling menguntungkan untuk kliennya dalam segi servis, rate, dan lainnya. PT Jaya Perkasa Wibawa juga senantiasa melakukan evaluasi perusahaan, agar dapat membenahi areaarea yang memiliki kekurangan ataupun menemukan hal-hal yang berpotensi menjadi masalah di kemudian hari (wawancara langsung dengan Andri Sumanjaya pada 4 November 2021 pukul 10.58 WIB). Jika sebuah perusahaan sudah mendapatkan kepercayaan customer-nya, citra baik yang dimiliki pun akan terus meningkat.

Selain dengan klien, citra baik perusahaan di mata mitra kerja juga tidak luput untuk ditingkatkan oleh pihak public relations. Tim hubungan masyarakat akan selalu menjaga hubungan yang baik dengan relasi PT. Jaya Perkasa Wibawa, seperti perusahaan mitra, pihak bank, maupun pihak asuransi. Relasi pun diperluas, demi menggapai cakupan pasar yang lebih luas dan pembentukan citra yang lebih baik lagi. 
PT. Jaya Perkasa Wibawa dalam upaya meningkatkan citra akan mengadakan acara pertemuan bersama para relasi, seperti perusahaan afiliasi, pihak bank, maupun asuransi atau justru menghadiri acara yang dibuat oleh perusahaan lain (wawancara langsung dengan Andri Sumanjaya pada 4 November 2021 pukul 10.58 WIB). Public Relations PT. Jaya Perkasa Wibawa juga menjalin kerja sama dengan media untuk mengiklankan jasa layananannya (wawancara langsung dengan Antonius Bayu Cahyadi pada 4 November 2021 pukul 10.58 WIB).

Sayangnya di tengah kondisi Tanah Air saat ini yang masih belum pulih sepenuhnya dari pandemi, agen PT. Jaya Perkasa Wibawa terpaksa menghadapi beberapa kendala selama melakukan promosi. Terbatasnya kesempatan untuk bertemu tatap dengan calon nasabah membuat agen kesulitan untuk mencari nasabah bank garansi baru. Jalan keluar dari kendala ini adalah melakukan penawaran via surat elektronik, namun respons yang didapat cenderung lama. Hubungan antara perusahaan dengan klien dan calon customer dapat merenggang karena hal ini, yang kemudian berdampak pada citra perusahaan yang dimiliki PT. Jaya Perkasa Wibawa. Untuk itu, public relations PT. Jaya Perkasa Wibawa bekerja lebih kuat lagi dalam menjaga hubungan dengan klien yang sudah ada dan memperluas relasi supaya nama PT. Jaya Perkasa Wibawa dapat didengar oleh cakupan masyarakat yang lebih luas lagi (wawancara langsung dengan Santana Adi Kusuma pada 4 November 2021 pukul $10.58 \mathrm{WIB})$.

\section{Simpulan}

Public relations dari PT. Jaya Perkasa telah cukup berhasil dalam menjaga hubungan antara individu dalam perusahaan. Tim hubungan masyarakat PT. Jaya Perkasa Wibawa kerap mengumpulkan para staf dan karyawan untuk melakukan evaluasi bersama, terutama ketika perusahaan sedang dihadapkan dengan sebuah masalah berupa target yang tidak tercapai. Selama proses evaluasi, para staf akan membahas terlebih dahulu masalah atau kekurangan yang ada pada tim, serta mencaritahu bersama-sama penyebab dari permasalahan tersebut bisa terjadi. Setelah terkumpul, tim akan kembali melakukan musyawarah guna menentukan langkah yang harus diambil setelahnya demi mencapai target yang sudah ditentukan. Dengan begitu, semua karyawan memiliki hak untuk menyampaikan pendapat dan menuangkan isi pikirannya. Citra yang dimiliki PT Jaya Perkasa Wibawa sudah dapat digolongkan baik. Perusahaan agen penjaminan ini telah menjadi harapan, baik untuk para karyawan maupun klien-kliennya. Komunikasi antarindividu dalam ruang lingkup perusahaan pun terjaga dengan cukup baik.

\section{Ucapan Terima Kasih}

Peneliti ingin mengucapkan terima kasih kepada Fakultas Ilmu Komunikasi Universitas Tarumanagara, narasumber, serta semua pihak yang turut membantu peneliti sehingga penelitian ini dapat diselesaikan.

\section{Daftar Pustaka}

Dewi, W. A. F. (2020). Dampak COVID-19 terhadap Implementasi Pembelajaran Daring di Sekolah Dasar. EDUKATIF J. ILMU Pendidik., vol. 2, no. 1, pp. 55-61. 
Fauziyah, Ulfah Mulyana. (2017). Strategi Promosi Produk Asuransi Jiwa Syariah Melalui Social Media (PT. Prudential Life Assurance Studi Kasus Prodigy AgencyMenara Thamrin). Skripsi thesis, Fakultas Agama Islam Universitas Muhammadiyah Jakarta.

Kennedy, R dan Suhendarto, B. P.. (2020). Diskursus Hukum: Alternatif Pola Pengisian Jabatan Kepala Daerah di Masa Pandemi Covid-19. J. Pembang. Huk. Indones., vol. 2, no. 2, pp. 188-204.

Pakpahan, A. Kristian. (2020). COVID-19 dan Implikasi Bagi Usaha Mikro, Kecil, dan Menengah," J. Ilm. Hub. Int., vol. 0, no. 0, pp. 59-64.

Pradana, A. A. Pradana, Casman C., dan Nur'aini, N. (2020) Pengaruh Kebijakan Social Distancing pada Wabah COVID-19 terhadap Kelompok Rentan di Indonesia. J. Kebijak. Kesehat. Indones. JKKI, vol. 9, no. 2, pp. 61-67.

Syafrida, S. dan Hartati, R. (2020). Bersama Melawan Virus Covid 19 di Indonesia," SALAM J. Sos. dan Budaya Syar-i, vol. 7, no. 6, pp. 495-508.

Sugiyono. (2015). Metode Penelitian Pendidikan: Pendekatan Kuantitatif, Kualitatif, dan $R \& D$. Bandung: Alfabeta. 